\section{Analisis Pengelolaan dan Pengendalian Piutang Pada Unit Pengelola Kegiatan (UPK) Kecamatan Ponggok Kabupaten Blitar}

\author{
Berti Dila Septiana*, Sura Klaudia, Kristya Damayanti \& \\ Tetty Widiyastuti
}

Sekolah Tinggi Ilmu Ekonomi Kesuma Negara, Blitar, Indonesia

\section{Short Report}

AKURASI

\title{
Abstract
}

Poverty is one of the problems that often occurs in Indonesia. Therefore, through the Unit Pengelola Kegiatan (UPK), the government made a Simpan Pinjam Perempuan (SPP) program in revolving funds provided without any collateral, so the risk that often occurs is bad credit arrears. This causes a decrease in assets or a deficit and an increasing number of bad debts, so good management and control are needed to reduce the number of complex or uncollectible receivables. The purpose of this paper is to identify and analyze the role of management and control applied by the UPK Ponggok District, Blitar Regency, in minimizing bad debts. This research is qualitative research with data collection methods with interviews and documentation. The results of this study indicate that (1) Receivable management applied by the UPK Ponggok Subdistrict, Blitar Regency is quite good, especially in credit standards, credit requirements, and applied receivable collection policies, but in the receivables management applied there is no receivables measurement ratio policy. (2) The control of receivables that was implemented did not go well because there were still various irregularities and discrepancies between the implementation and the applicable Standard Operating Procedure.

\section{Keywords:}

Account receivable management, account receivable control, uncollected receivable, unit pengelola kegiatan (upk), simpan pinjam perempuan (spp)

Corresponding Author:

Berti Dila Septiana

STIE Kesuma Negara

Email : bertidila@gmail.com

DOI: https://doi.org/10.36407/akurasi.v3i2.469

Received: 10 Aug 2021

Accepted: 25 Nov 2021

Online: 30 Dec 2021

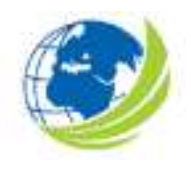

Akurasi: Jurnal Riset Akuntansi dan Keuangan, Vol 3, No.3, 2021, pp. 127 - 136

eISSN 2685-2888

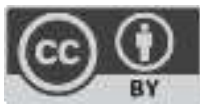

(C) The Author(s) 2021

CC BY This license allows reusers to distribute, remix, adapt, and build upon the material in any medium or format, so long as attribution is given to the creator. The license allows for commercial use. 


\section{PENDAHULUAN}

Permasalahan ekonomi sering terjadi pada negara berkembang, dan Indonesia merupakan salah satu negara berkembang yang juga memiliki masalah stabilitas ekonomi. Oleh sebab itu pemerintah mengeluarkan berbagai program dengan harapan agar kemiskinan di Indonesia dapat diminimalisir, namun nyatanya beberapa program cenderung tidak berkelanjutan. Salah satu program nasional yang berdampak positif terhadap pertumbuhan ekonomi di Indonesia khususnya ekonomi mikro adalah PNPM-MPd yang dikelola oleh Unit Pengelola Kegiatan (UPK). UPK membantu dalam pemberdayaan masyarakat untuk meningkatkan kesejahteraan dan kesempatan kerja bagi masyarakat miskin pedesaan secara mandiri melalui peningkatan partisipasi masyarakat dengan berbagai program. Salah satu program yang dikelola oleh UPK adalah program dana bergulir berupa Simpan Pinjam Perempuan (SPP). Simpan Pinjam Perempuan (SPP) merupakan program simpan pinjam yang diberikan kepada masyarakat khususnya perempuan berupa dana bergulir yang diberikan tanpa syarat agunan dengan suku bunga yang rendah, sehingga risiko yang sering terjadi adalah piutang yang susah atau bahkan tidak bisa ditagih. Hal tersebut juga terjadi pada SPP yang dikelola oleh UPK Kecamatan Ponggok Kabupaten Blitar. Simpan Pinjam Perempuan (SPP) yang dikelola oleh UPK Kecamatan Ponggok Kabupaten Blitar mengalami piutang macet yang menyebabkan UPK Kecamatan Ponggok Kabupaten Blitar mengalami penurunan asset atau defisit dan jumlah piutang macet yang semakin bertambah, sehingga dalam pelaksanaan program SPP dibutuhkan pengelolaan dan pengendalian piutang yang baik guna mengurangi dan meminimalisir adanya piutang yang susah atau bahkan tidak bisa tertagih

\section{METODE}

\section{Jenis Penelitian}

Penelitian ini merupakan penelitian kualitatif yang dimaksudkan untuk memperoleh berbagai informasi yang berhubungan dengan keadaan di lapangan dan melihat kaitan antara variabel-variabel yang ada serta mengetahui dan menggambarkan dengan jelas bagaimana keadaan di lapangan pada saat terjun langsung melakukan penelitian mengenai pengelolaan dan pengendalian piutang pada UPK Kecamatan Ponggok Kabupaten Blitar.

\section{Subjek Penelitian}

Dalam penelitian kualitatif, subjek penelitian yang digunakan adalah informan. Adapun informan yang penulis jadikan sebagai narasumber dalam proses wawancara, diantaranya; (1) Pengurus Unit Pengelola Kegiatan (UPK) Kecamatan Ponggok Kabupaten Blitar (2) Badan Kerjasama Antar Desa (BKAD) Kecamatan Ponggok Kabupaten Blitar (3) Tim Verifikasi UPK Kecamatan Ponggok Kabupaten Blitar (4) Kreditur atau peminjam yang tergabung dalam kelompok Simpan Pinjam Perempuan (SPP) Kecamatan Ponggok Kabupaten Blitar. Sedangkan obyek penelitian yang digunakan adalah data-data pendukung yang ada di Unit Pengelola Kegiatan (UPK) Kecamatan Ponggok Kabupaten Blitar.

\section{Metode Pengumpulan Data}

Untuk mencari dan mengumpulkan data adalah dengan; (1) Wawancara, dilakukan dengan cara tanya jawab sambil bertatap muka langsung kepada informan. Jenis wawancara yang digunakan adalah wawancara tak terstruktur. Pedoman wawancara hanya berupa garis besar dari permasalahanpermasalahan yang ditanyakan. (2) Dokumentasi, dilakukan dengan cara mengambil data-data yang ada dengan membuat salinan data-data tersebut dengan menggunakan kamera penulis agar dapat mempermudah dan mempercepat penulis.

\section{Teknik Analisis}

Teknik analisis data yang digunakan adalah; (1) Melakukan wawancara kepada narasumber terkait 
pengelolaan piutang dan pengendalian piutang yang diterapkan oleh UPK Kecamatan Ponggok Kabupaten Blitar (2) Mengumpulkan data-data yang ada yang berkaitan dengan permasalahan dalam penelitian (3) Menganalisa data dengan cara menggolongkan, menajamkan, dan memilih data mana yang relevan dan tidak relevan untuk digunakan dalam penelitian (4) Menyajikan data yang sudah dianalisis tersebut dalam bentuk laporan (5) Menarik kesimpulan sebagai jawaban dari rumusan masalah dalam penelitian.

\section{Pengujian Keabsahan Data}

Agar data yang diperoleh dapat dipertanggungjawabkan sebagai penelitian ilmiah, maka perlu dilakukan uji keabsahan data yang meliputi; (1) Perpanjangan pengamatan, untuk meningkatkan hubungan antara peneliti dan narasumber agar semakin terbuka dan menimbulkan rasa percaya untuk memberikan data yang banyak dan lengkap (2) Triangulasi, yang meliputi sumber, metode, dan teori (3) Uji transferbilitas memberikan penjabaran yang jelas, rinci dan sistematis terhadap hasil peneliatian agar mudah dipahami dan dapat diterapkan (4) Uji Dependabilitas, yaitu penulis melakukan audit sacara keseluruhan proses penelitian dengan cara berkomunikasi bersama pembimbing (5) Uji konfirmabilitas, yaitu hasil dari penelitian merupakan data asli dan tidak berbeda dari tempat penelitian sehingga data-data tersebut dapat dipertanggungjawabkan dan dikonfirmasi kepada sumbernya.

\section{HASIL DAN PEMBAHASAN}

\section{Analisis Pengelolaan Piutang}

(a) Standar Kredit

Standar kredit yang diterapkan oleh UPK Kecamatan Ponggok Kabupaten Blitar telah dilaksanakan secara efektif dan sesuai dengan SOP yang berlaku. Hal tersebut dibuktikan dengan dengan adanya buku proposal perguliran SPP yang berisikan berkas administrasi para kelompok SPP.

(b) Persyaratan Kredit

Persyaratan kredit yang diterapkan oleh UPK Kecamatan Ponggok Kabupaten Blitar telah dilaksanakan secara efektif dan sesuai dengan SOP yang berlaku. Hal tersebut dibuktikan dengan; (1) Pengalokasian dana SPP telah di kondisikan berdasarkan dengan kemampuan kelompok (2) Pemberikan ketetapan bunga tanpa adanya potongan dalam bentuk apapun (3) Pemberian Insentif Pengembalian Tepat Waktu (IPTW) telah dilaksanakan sesuai dengan SOP.

(c) Kebijaksanaan Pengumpulan Piutang

Kebijaksanaan pengumpulan piutang yang diterapkan oleh UPK Kecamatan Ponggok Kabupaten Blitar telah dilaksanakan sesuai dengan SOP UPK Kecamatan Ponggok Kabupaten Blitar. Hal tersebut dibuktikan dengan piutang yang diberikan oleh UPK Kecamatan Ponggok Kabupaten Blitar merupakan dana bergulir yang berdasarkan atas dasar kepercayaan dan diberikan tanpa adanya agunan atau jaminan, sehingga untuk menghindari adanya tunggakan terhadap angsuran yang dilakukan oleh kelompok pemanfaat maka UPK membuat beberapa kebijakan.

\section{(d) Rasio Pengukuran Piutang}

Dalam pengelolaan piutang yang diterapkan oleh UPK Kecamatan Ponggok Kabupaten Blitar tidak menerapkan rasio pengukuran piutang, sedangkan rasio pengukuran piutang dapat digunakan untuk menilai piutang menggunakan rasio-rasio keuangan yang berhubungan 
dengan piutang agar tidak terjadi peningkatan risiko akan tidak tertagihnya piutang tersebut yang kemudian akan merujuk pada kebangkrutan.

\section{Analisis Pengendalian Piutang}

\section{(a) Lingkungan Pengendalian}

Lingkungan pengendalian terdiri dari beberapa faktor umum yang menentukan sifat dari suatu organisasi. Setiap bagian dari struktur organisasi UPK Kecamatan Ponggok Kabupaten Blitar mempunyai hak, tugas, wewenang dan tanggung jawab masing-masing yang telah di tetapkan sesuai dengan kemampuan sumber daya manusia. Selain itu, UPK Kecamatan Ponggok Kabupaten Blitar memiliki aturan-aturan yang sesuai dengan Standar PTO PNPM-Mandiri Perdesaan atau Anggaran Dasar dan Anggaran Rumah Tangga (AD/ART) BKAD dan SOP-SOP turunannya yang wajib ditaati, namun dalam pelaksanannya, penerapan lingkungan pengendalian di UPK Kecamatan Ponggok Kabupaten Blitar tidak berjalan sesuai dengan SOP dan ketentuan yang telah ditetapkan oleh UPK Kecamatan Ponggok Kabupaten Blitar.

\section{(b) Penentuan Risiko}

Semua aktivitas terutama pada sebuah perusahaan, lembaga, atau organisasi pasti menghadapi sebuah risiko baik internal ataupun eksternal dalam mencapai suatu tujuan perusahaan. Hal tersebut juga terjadi pada UPK Kecamatan Ponggok Kabupaten Blitar. Risiko yang terjadi pada UPK Kecamatan Ponggok adalah adanya kredit macet pada program SPP.

\section{(c) Aktivitas Pengendalian}

Untuk menghadapi resiko-resiko yang ada, aktivitas pengendalian yang diterapkan oleh UPK Kecamatan Ponggok Kabupaten Blitar meliputi verifikasi dua tahap yaitu verifikasi proposal dan verifikasi kelompok serta sistem tanggung renteng. Namun dalam pelaksanaannya tidak semua berjalan dengan baik, dibuktikan dengan; (1) Verifikasi (a) Verifikasi Proposal, pihak UPK Kecamatan Ponggok Blitar telah melaksanakannya sesuai dengan SOP UPK Kecamatan Ponggok Blitar dan Standar PTO PNPM-Mandiri Perdesaan yang diperkuat dengan adanya buku proposal perguliran Simpan Pinjam Perempuan (SPP) (b) Verifikasi Kelompok SPP, dalam pelaksanaannya UPK Kecamatan Ponggok Kabupaten Blitar kurang ketat dalam melakukan verifikasi kelompok SPP yang dapat dibuktikan dengan permasalahan yang terjadi pada kelompok pemanfaat program SPP dimana kelompok tersebut melakukan penyelewengan (2) Sistem Tanggung Renteng, dalam pelaksanannya tidak berjalan sesuai dengan aturan dan kesepakatan bersama antara UPK dan kelompok peminjam. Dibuktikan dengan permasalahan yang terjadi pada kelompok pemanfaat dimana kelompok tersebut mengalami kemacetan angsuran. Untuk memperkuat sistem tanggung renteng UPK Kecamatan Ponggok membuat surat pernyataan tanggung renteng dan tabungan kelompok berupa jaminan, namun dalam pelaksanaan dapat dikatakan belum maksimal.

(d) Informasi dan Komunikasi

Informasi dan komunikasi penting dilakukan dan harus terjalin dengan baik, namun dalam pelaksanaannya, komunikasi antara atasan dan bawahan pada UPK Kecamatan Ponggok Kabupaten Blitar kurang baik. Hal ini terjadi dikarenakan adanya kekosongan bagian atau jabatan ketua pada struktur organisasi UPK Kecamatan Ponggok Kabupaten Blitar. Hal tersebut tentu saja berdampak pada kinerja karyawan UPK Kecamatan Ponggok Kabupaten Blitar. 


\section{(e) Pengawasan}

Pengawasan dilakukan sebagai suatu proses atau cara untuk menilai kualitas dari pelaksanaan pengendalian pada UPK Kecamatan Ponggok Kabupaten Blitar. Pengawasan yang diterapkan UPK Kecamatan Ponggok Kabupaten Blitar tidak berjalan dengan baik karena masih terdapat penyelewengan-penyelewengan yang terjadi, baik dari pihak UPK Kecamatan Ponggok Kabupaten Blitar atau para pemanfaat program SPP.

\section{Pembahasan}

\section{Analisis Pengelolaan Piutang}

\section{(a) Standar Kredit}

Standar kredit yang diterapkan telah dilaksanakan secara efektif dan sesuai dengan SOP yang berlaku. Adanya standar kredit dalam pengelolaan piutang dapat digunakan untuk menentukan kemauan dan kemampuan pemanfaat dan dapat dijadikan sebagai kualitas minimal kelayakan kredit atau peminjaman, sehingga dengan adanya standar kredit tersebut tentunya UPK Kecamatan Ponggok Kabupaten Blitar dapat meningkatkan kualitas dari program SPP tanpa menimbulkan adanya risiko piutang tak tetagih. Sedangkan dalam penelitian yang dilakukan oleh Widayanti (2019) dalam pengelolaan piutangnya tidak memberlakukan standar kredit dalam menilai kemauan dan kemampuan calon pelanggan baru.

\section{(b) Persyaratan Kredit}

Persyaratan kredit yang diterapkan telah dilaksanakan dengan efektif dan sesuai dengan SOP yang berlaku. Persyaratan kredit yang terdapat dalam pengelolaan piutang dapat digunakan untuk meningkatkan angka penjualan kredit dan untuk mempengaruhi pemanfaat agar segera membayar tanggungannya pada program SPP yang dikelola UPK Kecamatan Ponggok Kabupaten Blitar, dengan adanya persyaratan kredit dapat memperkecil risiko adanya piutang tak tertagih. IPTW yang diberikan oleh UPK Kecamatan Ponggok Kabupaten Blitar dapat bermanfaat terhadap pengelolaan piutang sehingga dapat meminimalisir adanya piutang tak tertagih. Hal tersebut sejalan dengan penelitian yang dilakukan oleh Ihdil (2019), IPTW merupakan suatu penghargaan sekaligus ajakan yang diberikan oleh UPK terhadap kelompokkelompok SPP untuk melakukan pembayaran tepat waktu sehingga dapat meghindari terjadinya piutang tak tertagih.

\section{(c) Kebijaksanaan Pengumpulan Piutang}

Kebijaksanaan pengumpulan piutang yang diterapkan telah dilaksanakan sesuai dengan SOP UPK Kecamatan Ponggok Kabupaten Blitar. Kebijakan pengumpulan piutang yang terdapat dalam pengelolaan piutang dapat digunakan sebagai cara atau syarat atau peraturan dalam pengumpulan piutang pada program SPP yang dikelola oleh UPK Kecamatan Ponggok Kabupaten Blitar. UPK memberikan piutang berupa dana bergulir yang berdasarkan atas dasar kepercayaan. Pinjaman yang terdapat pada program SPP diberikan tanpa adanya agunan atau jaminan. Untuk menghindari adanya tunggakan terhadap angsuran yang dilakukan kelompok maka kebijakan pengumpulan piutang yang diterapkan UPK Kecamatan Ponggok Kabupaten Blitar yaitu; (1) Sebelum jatuh tempo pembayaran, UPK memberikan teguran yang bersifat mengingatkan (2) Sebelum melakukan angsuran kepada UPK, kelompok pemanfaat harus mengumpulkan angsuran secara kolektif (3) Kelompok yang belum dapat melakukan pelunasan pada jatuh tempo maka akan diadakan pertemuan antara kelompok bersama dengan UPK dan BKAD untuk membahas dan menyelesaikan masalah secara kekeluargaan (4) Apabila pertemuan telah dilaksanakan dan kelompok tetap tidak melakukan pelunasan maka Bersama BKAD mengadakan rapat intern bersama dengan Kepala Desa yang bersangkutan. 
Kebijakan pengumpulan piutang tersebut sejalan dengan penelitian yang dilakukan oleh Ihdil (2019), sebelum jatuh tempo angsuran pihak UPK memberikan teguran baik secara langsung ataupun telepon dan untuk pembayaran angsuran semua anggota wajib mengumpulkan angsuran ke bendahara kelompok kemudian bendahara menyetorkan pada UPK.

\section{(d) Rasio Pengukuran Piutang}

Dalam pengelolaan piutang pada program SPP yang dikelolanya, UPK Kecamatan Ponggok Kabupaten Blitar tidak menerapkan rasio pengukuran piutang. Sedangkan dalam penelitan yang dilakukan Widayanti (2019), menerapkan rasio pengukuran piutang untuk mengukur dan menilai piutang yang terjadi selama satu periode adalah menggunakan sebuah sistem informasi akuntansi. Rasio pengukuran piutang dapat digunakan oleh UPK Kecamatan Ponggok Kabupaten Blitar untuk melihat sejauhmana kemampuan UPK Kecamatan Ponggok Kabupaten Blitar dalam mengukur, menilai dan menagih piutang pada program SPP yang dikelolanya agar tidak terjadi kebrangkutan. Hal tersebut sejalan dengan jurnal penelitian yang dilakukan oleh Suwetja, Rompas, dan Elim (2018), rasio pengukuran piutang sangat diperlukan dalam suatu perusahaan karena semakin lama umur piutang maka semakin besar pula kerugian yang akan ditanggung perusahaan dan kemungkinan tidak tertagih juga semakin besar. Sebaiknya UPK Kecamatan Ponggok Kabupaten Blitar menerapkan rasio pengukuran piutang, karena pengukuran piutang ini dapat digunakan untuk melihat sejauhmana kemampuan UPK Kecamatan Ponggok Kabupaten Blitar dalam menagih piutang pada program SPP yang dikelolanya.

\section{Analisis Pengendalian Piutang}

\section{(a) Lingkungan Pengendalian}

Lingkungan pengendalian yang diterapkan tidak berjalan sesuai dengan SOP. Karena dalam lingkungan pengendalian, pemisahan fungsi dari tiap-tiap bagian sangat perlu dilakukan agar dapat melakukan tugas dan tanggung jawab secara penuh, namun pada struktur kepengurusan UPK Kecamatan Ponggok Kabupaten Blitar, terdapat bagian atau divisi yang memiliki tugas ganda, sehingga dalam melaksanakan tugas dan tanggungjawabnya tidak bisa maksimal, maka sangat perlu adanya pemisahan tugas pada struktur organisasi UPK Kecamatan Ponggok Kabupaten Blitar. Sedangkan penelitian yang dilakukan oleh Suwetja, Rompis, dan Elim (2018), lingkungan pengendalian yang diterapkan pada PT. Bank Rakyat Indonesia Cabang Bitung telah berjalan dengan baik karena adanya pemisahan tugas sehingga dapat mengurangi ancaman terhadap resiko yang mungkin akan terjadi.

\section{(b) Penentuan Risiko}

Dalam pencapaian suatu sasaran pengendalian selalu terdapat risiko-risiko yang dapat mengganggu, sehingga perlu menentukan bagaimana mengelola resiko-resiko tersebut. Program SPP yang dikelola UPK Kecamatan Ponggok Kabupaten Blitar merupakan program simpan pinjam berupa dana bergulir tanpa agunan, sehingga risiko yang sering terjadi adalah kredit macet yang disebabkan karena adanya faktor-faktor tertentu baik yang disengaja atau tidak disengaja yang dialami oleh peminjam atau pemanfaat sehingga tidak atau belum mampu untuk melunasi kredit tersebut. Hal tersebut sejalan dengan penelitian yang dilakukan oleh Wahdiah (2017), risiko yang harus ditanggung UPK selain akibat dari adanya tenggang waktu pengembalian adalah piutang tanpa jaminan serta risiko lain yang menjadi tanggungan adalah risiko yang disengaja oleh nasabah ataupun resiko yang tidak disengaja oleh nasabah. 
(c) Aktivitas Pengendalian

(1) Verifikasi (a) Verifikasi Proposal, dalam pelaksanaannya telah berjalan sesuai dengan SOP UPK Kecamatan Ponggok Blitar dan Standar PTO PNPM-Mandiri Perdesaan yang diperkuat dengan adanya buku proposal perguliran SPP yang berisikan berkas administrasi bahwa para kelompok SPP telah melengkapi data-data yang nantinya akan dipergunakan untuk mengajukan pinjaman di UPK Kecamatan Ponggok Kabupaten Blitar (b) Verifikasi Kelompok SPP, untuk mengecek dan mengidentifikasi latar belakang dan kebenaran dari calon pemanfaat. Tahap verifikasi kelompok penting karena dapat dijadikan sebagai tindak lanjut dalam menentukan dan mengambil keputusan apakah berhak atau tidak berhak calon pemanfaat melakukan pinjaman, namun dalam pelaksanaannya kurang ketat. Dibuktikan dengan adanya penyelewengan dari ketua kelompok pemanfaat yang menggunakan uang SPP kelompok untuk kepentingan pribadi. Hasil penelitian di atas sejalan dengan penelitian yang dilakukan Ihdil (2019), verifikasi yang diterapkan oleh UPK Kecamatan Baraka Kabupaten Enrekang adalah verifikasi melalui 2 (dua) tahap yaitu verifikasi atas proposal dan verifikasi kelompok SPP.

(2) Sistem Tanggung Renteng, sistem tanggung renteng yang diterapkan tidak berjalan sesuai dengan aturan dan kesepakatan bersama antara UPK dan kelompok peminjam. Dibuktikan dengan permasalahan dari kelompok pemanfaat yang belum dapat melakukan pelunasan dikarenakan adanya kemacetan angsuran dari anggota kelompok tersebut. Sedangkan dalam perjanjian tanggung renteng yang telah disepakati bersama, setiap kelompok bersedia dan sanggup untuk saling menanggung kewajiban dari anggota kelompok yang tidak dapat membayar kembali pinjaman kepada UPK Kecamatan Ponggok Kabupaten Blitar. Dalam penelitian yang dilakukan Nurazizah (2018), tanggung renteng yang dijalankan dalam mengelola piutang macet pada PNPM Mandiri Kecamatan Medang Deras Kabupaten Batubara adalah cukup bagus. Dalam pelaksanaan yang dilakukan UPK Kecamatan Ponggok Kabupaten Blitar untuk memperkuat sistem tanggung renteng belum maksimal karena dalam pelaksanaannya UPK kurang tegas dalam penerapan surat pernyataan tanggung renteng dan tabungan kelompok yang telah disepakati bersama. Hal tersebut diperkuat dengan adanya permasalahan dari kelompok pemanfaat yang belum dapat melakukan pelunasan dikarenakan adanya anggota kelompok yang meninggal dunia dan ketua kelompok tersebut kesulitan dalam melakukan penagihan.

\section{(d) Informasi dan Komunikasi}

Informasi dan komunikasi yang terjalin di UPK Kecamatan Ponggok Kabupaten Blitar kurang baik, hal ini terjadi karena adanya kekosongan jabatan ketua UPK. Sehingga, untuk berkomunikasi kepada atasan harus kepada ketua BKAD sebagai penanggung jawab selama kekosongan jabatan ketua di UPK Kecamatan Ponggok Kabupaten Blitar sejak tahun 2015. Sedangkan, waktu atau jam kerja BKAD berbeda dengan karyawan UPK Kecamatan Ponggok Kabupaten Blitar.

\section{(e) Pengawasan}

Pengasawan yang diterapkan adalah dengan adanya peran BKAD serta Badan Pengawas UPK (BP-UPK) untuk mengawasi jalannya seluruh aspek organisasi sesuai dengan SOP dan aturanaturan yang berlaku, namun dalam pelaksanaannya tidak berjalan dengan baik. Terdapat penyelewengan-penyelewengan yang dilakukan baik dari pihak UPK atau pemanfaat program SPP, maka sebaiknya BP-UPK harus melakukan pengawasan secara professional agar dapat memastikan bahwa UPK beserta seluruh unit kerja dan sektor usaha produktif di dalamnya bekerja, bertindak, melaksanakan kegiatan-kegiatan secara benar dalam rangka mencapai target misi dan visi organisasi. 
Piutang yang dikelola UPK Kecamatan Ponggok Kabupaten Blitar telah sejalan dengan unsurunsur kredi sebagai berikut; (1) Kepercayaan, dana yang dikelola merupakan dana amanah yang dialokasikan dengan ketentuan-ketentuan yang berlaku dan tanpa agunan atau jaminan (2) Kesepakatan, kesepakatan dilakukan oleh UPK dan pemanfaat mengenai pemberian pinjaman, aturanaturan, dan kesanggupan tanggung renteng dan bunga dalam penjiman (3) Jangka waktu, batas waktu peminjaman yang telah disepakati bersama (4) Risiko, risiko internal yang dihadapi adalah adanya tunggakan kredit macet, selain itu penyebab besarnya risiko yang ditanggung UPK Kecamatan Ponggok Kabupaten Blitar adalah piutang tanpa agunan (5) Balas jasa, pada dasarnya tujuan program SPP adalah untuk pemberdayaan dan kesejahteraan masyarakat, meskipun demikian setiap pinjaman akan dikenakan biaya administrasi yang disebut dengan jasa pinjaman atau bunga.

\section{KESIMPULAN}

Berdasarkan hasil pembahasan dapat ditarik kesimpulan sebagai berikut; (1) Pengelolaan piutang cukup baik terutama pada standar kredit, persyaratan kredit, dan kebijakan pengumpulan piutang yang diterapkan, namun dalam pengelolaan piutang yang diterapkan tidak terdapat kebijakan rasio pengukuran piutang (2) Pengendalian piutang tidak berjalan dengan baik karena pada lingkungan pengendalian yang diterapkan terdapat karyawan dengan tugas ganda dan berakibat pada kinerja karyawan tersebut, penentuan risiko yang terjadi adalah sering terjadi kredit macet, aktivitas pengendalian yang diterapkan tidak semuanya berjalan sesuai dengan kebijakan dan prosedur yang telah dibuat dan disepakati bersama, informasi dan komunikasi yang terjalin antara atasan dan bawahan kurang baik, pengawasan yang diterapkan tidak berjalan dengan baik karena masih terdapat penyelewengan yang terjadi baik dari pihak UPK atau para pemanfaat program SPP.

Berdasarkan uraian hasil analisis terhadap pengelolaan dan pengendalian piutang yang diterapkan pada SPP yang dikelola UPK Kecamatan Ponggok Kabupaten Blitar dalam meminimalisir piutang tak tertagih, penulis memberikan saran sebagai berikut; (1) Menerapkan kembali konsep awal dari SPP untuk pemberdayaan perempuan dalam mempercepat proses pemenuhan kebutuhan pendanaan usaha ataupun sosial dasar, kelompok pemanfaat atau peminjam harus memiliki satu tujuan yang sama, bukan hanya membentuk kelompok untuk melakukan peminjaman uang tanpa adanya tujuan dan arah yang jelas (2) Dalam tahap verifikasi dan analisa oleh UPK kepada calon pemanfaat, tim verifikasi harus lebih memperhatikan kondisi, latar belakang, dan keadaan dari calon pemanfaat tersebut apakah layak atau tidak layak untuk diberikan pinjaman (3) Dalam menjamin keberlangsungan piutangnya, disarankan untuk memperjelas pemahaman mengenai sistem tanggung renteng kepada para pemanfaat, serta selalu menerapkan nilai-nilai yang terkandung pada sistem tanggung renteng dan juga selalu menjalin kerjasama yang baik dari semua pihak, seperti pengurus UPK, Kepala Desa, Ketua kelompok dan anggota kelompok pemanfaat program SPP (4) Karena pinjaman yang diberikan UPK Kecamatan Ponggok Kabupaten Blitar adalah pinjaman tanpa syarat agunan maka upaya yang harus dilakukan UPK adalah melakukan pendekatan kepada para pemanfaat, terutama pada pemanfaat dengan tunggakan angsuran yang lebih dari 3 (tiga) kali angsuran atau lebih (5) Memberikan sanksi lokal yaitu apabila salah satu kelompok di satu desa tidak melunasi hutangnya maka akan berimbas kepada kelompok lain di desa tersebut tidak bisa mengajukan dan mendapatkan pinjaman lagi dari UPK (tidak diikut sertakan desa tersebut dalam program SPP (6) Pemberian bunga tambahan yang dilakukan UPK Kecamatan Ponggok Kabupaten Blitar sebesar 0,5\% yang sifatnya tidak wajib bagi seluruh kelompok pemanfaat, sebaiknya dijadikan ketentuan wajib, karena nantinya dapat membantu meringankan kelompok pemanfaat apabila belum bisa melakukan angsuran.

\section{REFERENSI}

Ardiprawiro. (2015). Dasar Manajemen Keuangan. Bandung: Universitas Gunadarma. 
Budi, H.I.S. (2011). Bijak Mengelola piutang Smart In Accounting Receivable. Jakarta: PT Alex Media Komputindo.

Departemen Dalam Negeri Republik Indonesia. (2010). Penjelasan PTO (Petunjuk Teknis Operasional) Program Nasional Pemberdayaan Masyarakat (PNPM). Indonesia: Direktorat Jendral Pemberdayaan Masyarakat Dan Desa.

Hayati, A.R. (2012). Analisis Efektivitas Pengelolaan Dan Sistem Pengendalian Piutang Pada PT. Pelabuhan Indonesia IV (Persero) Cabang Terminal Petikemas Makassar. Skripsi, Program Studi Manajemen Fakultas Ekonomi Universitas Hasanuddin, Makassar.

Ihdil. (2019). Evaluasi Atas Sistem Pengendalian Piutang Pada SPP UPK PNPM Mandiri Pedesaan Kecamatan Baraka Kabupaten Enrekang. Skripsi, Program Studi Akuntansi Fakultas Ekonomi dan Bisnis Universitas Muhammadiyah, Makassar.

Jusup A.H. (2011). Dasar-Dasar Akuntansi (Edisi Tujuh. Jilid 2). Yogyakarta: Sekolah Tinggi Ilmu Ekonomi YKPN.

Kasmir. (2012). Bank dan Lembaga Keuangan Lainnya. Jakarta: PT. Raja Grafindo Persada.

Khusnah, S.A. (2018). Analisis Pengendalian Internal Piutang Usaha Untuk Efektivitas Pengelolaan Piutang Usaha Di Dealer PT. Putra Rinjani. Skripsi, Program Studi Akuntansi STIE Kesuma Negara, Blitar.

Mulyadi. (2016). Sistem Akuntansi (Edisi Empat). Jakarta: Salemba Empat.

Nurazizah. (2018). Pengendalian Intern Piutang Dalam Mengelola Piutang Macet (Studi Kasus Pada PNPM Mandiri Kecamatan Medang Deras Kabupaten Batubara). Skripsi, Program Studi Akuntansi Syariah Universitas Islam Negeri Sumatera Utara, Medan.

Nurhalizah, S. (2019). Peran Unit Pengelola Kegiatan (UPK) Program Nasional Pemberdayaan Masyarakat (PNPM) Mandiri Pedesaan Dalam Peningkatan Ekonomi Di Kecamatan Tompobulu Kabupaten Gowa (Ditinjau Dalam Perspektif Islam). Skripsi, Fakultas Ekonomi Dan Bisnis Islam UIN Alauddin, Makassar.

Siregar, T.A. (2019). Analisis Sistem Pengendalian Internal Piutang Usaha Untuk Meminimalkan Piutang Tak Tertagih Pada PT. Juang Jaya Abdi Alam Cabang Medan. Skripsi, Program Studi Akuntansi Syariah Fakultas Ekonomi dan Bisnis Islam Universitas Islam Negeri, Sumatera Utara.

Sudiba, K. dan Widanarto, M.V.C. (2016). Efektivitas Program Simpan Pinjam Perempuan (SPP) PNPM Mandiri Perdesaan Di Kecamatan Kuta Selatan Kabupaten Badung. E-Jurnal Ekonomi dan Bisnis Universitas Udayana, 5(2), 253-278. https://ojs.unud.ac.id/index.php/EEB/article/view/94 81

Suwetja, Rompas, dan Elim. (2018). Analisis Pengelolaan Piutang dan Kerugian Piutang Tak Tertagih Pada PT. Bank Rakyat Indonesia Cabang. Jurnal Riset Akuntansi Going Concer, 13(3), 285-293. https://ejournal.unsrat.ac.id/index.php/gc/article/download/20172/19779

Wahdiah. (2017). Pengendalian Piutang Pada Program Nasional Pemberdayaan Masyaralat Mandiri Perdesaan (PNPM-MPd) Di Kecamatan Astambul Kapubaten Banjar Kalimantan Selatan. Skripsi, Program Studi Ekonomi Syariah. Institut Agama Islam Negeri, Palangkaraya.

Warren, S.Carl et al. (2013). Pengantar Akuntansi-Adaptasi Indonesia (Buku 1). Jakarta: Salemba Empat.

Widayanti, I.H. (2019). Analisis Pengelolaan Piutang Dan Pengendalian Piutang Untuk Meningkatkan Efektivitas Penagihan Piutang Macet Di PDAM Tirta Binangun Kabupaten Kulon Progo. Skripsi, Program Studi Akuntansi. Sekolah Tinggi Ilmu Ekonomi YKPN, Yogyakarta. 


\section{DECLARATIONS}

\section{Funding}

The authors received no financial support for the research and publication of this article.

\section{Conflicts of interest/ Competing interests:}

The authors have no conflicts of interest to declare that are relevant to the content of this article.

\section{Data, Materials and/or Code Availability:}

Data sharing is not applicable to this article as no new data were created or analyzed in this study.

\section{How to cite this Article}

Septiana, B., Klaudia, S., Damayanti, K., \& Widiyastuti, T. (2022). Analisis Pengelolaan dan Pengendalian Piutang Pada Unit Pengelola Kegiatan (UPK) Kecamatan Ponggok Kabupaten Blitar. AKURASI: Jurnal Riset Akuntansi Dan Keuangan, 3(3), 127 - 136. 